Document downloaded from:

http://hdl.handle.net/10251/63097

This paper must be cited as:

Boni Aristizábal, A.; Gasper, D. (2012). Rethinking the Quality of Universities: How Can Human Development Thinking Contribute?. Journal of Human Development and Capabilities. 13(3):451-470. doi:10.1080/19452829.2012.679647.

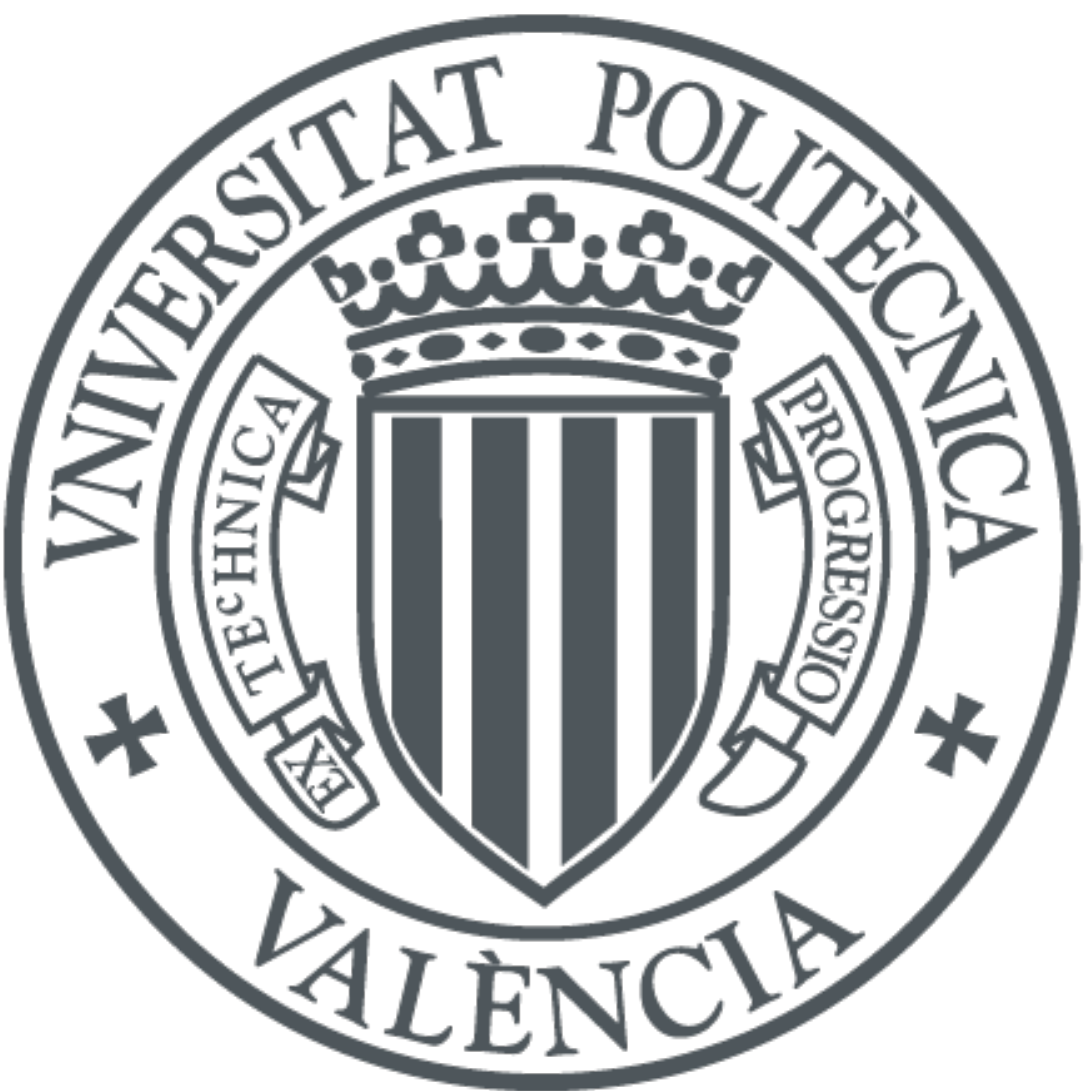

The final publication is available at

Copyright Taylor \& Francis

Additional Information 


\title{
Rethinking the quality of universities -- How can human development thinking contribute?
}

\begin{abstract}
University quality and its measurement have been strongly on the agenda of university policy since the 1980s. There is no consensus about what a good university is, but increasingly priority has been given to a narrow focus on contribution to supporting economic production and growth, as part of an economy- and market-centred conception of society. We argue that a human development approach is also very often relevant in educational policy and evaluation and can assist us to define and characterize a good university. From the following core values of human development - well-being, participation and empowerment, equity and diversity, and sustainability - we propose a list of dimensions for a human development orientation in research, teaching, social engagement and university governance, and then discuss the implications of these values and how they can be used in evaluation and steering of universities' work.
\end{abstract}




\section{Introduction}

What is, and what should be, the role of the university at the beginning of the $21 \mathrm{st}$ century? What are the goals of this institution and which ones might be appropriately added or strengthened? How then, correspondingly, should universities be evaluated?

In the second section of this paper we look at competing answers to these questions. In the third section we indicate relevant insights that a human development perspective can bring to this debate. The fourth section presents some key issues in the debate on quality of universities. The fifth section presents a proposal of possible dimensions to use in thinking about a quality higher education institution, taking the perspective of human development. We select four core values of human development (HD) - well-being, participation and empowerment, equity and diversity, and sustainability (Penz et al., 2011) - and we propose a list of dimensions for an HD orientation in research, teaching, community engagement and university governance, to be used in planning and evaluating university activities. For each combination of an activity-area and a core value, relevant indicators can be identified, depending on the specific context.

\section{The role of the university}

Various different answers are offered nowadays concerning the appropriate role, goals and performance indicators for universities. For instance, the Council of the European Union (2007:2) refers to the university as the "key element of Europe's drive to create a knowledge-based society and economy and improve its competitiveness". The OECD (2007: 11) says similarly: "HEIs [higher education institutions] must do more than simply educate and research - they must engage with others in their regions, provide opportunities for lifelong learning and contribute to the development of knowledgeintensive jobs which will enable graduates to find local employment and remain in their communities". The World Trade Organisation is another multilateral institution that has paid special attention to education. It considers, in its General Agreement on Trade in Services, that higher education is a product, an international service that can be purchased and sold by any international provider (Van Ginkel and Rodrigues, 2007: 48-49). 
Similar views can be found within the sphere of institutions more specifically engaged in international development. Thus, according to the World Bank, "tertiary education is necessary for the effective creation, dissemination, and application of knowledge, and for building technical and professional capacity" (World Bank, 2002:19). Likewise, the Millennium Project (Sachs, 2005), within the framework of the United Nations Millennium Development Goals, refers to universities as the entities able to provide the required capabilities to improve the scientific potential of a country, by creating scientific consultative bodies, promoting the commercial side of science and technology, promoting the development of infrastructures, and so on.

The five institutions highlighted above provide examples of views on education focused on economic competitiveness and efficiency. This approach is not the only one but has become perhaps the most widespread one nowadays. As Naidoo (2003:250) suggests, "the perception of higher education as an industry for enhancing national competitiveness and as a lucrative service that can be sold in the global marketplace has begun to eclipse the social and cultural objectives of higher education generally encompassed in the conception of higher education as a 'public good'. Relatedly, the belief that universities require a relative independence from political and corporate influence to function optimally [..] has been eroded". These visions, together with a general retraction in public policy have resulted in the implementation of new funding and regulatory frameworks based on neo-liberal market mechanisms and new managerialist principles (Avis, 1996; Deem, 1998, 2001; Dill, 1997; Marginson, 1997; Williams, 1997 all quoted in Naidoo, 2003: 250).

A further consequence of this has been the increased emphasis on performance and accountability assessment, with the accompanying use of performance indicators (Olsen and Peters, 2005). Among the different ways of assessing university performance, rankings have become a very popular way to measure university excellence. According to recent research carried out by the OECD, they have become key influences on university policies (Hazelkorn, 2007). The OECD study highlights that university officials 
throughout the world are incorporating those ranking results into their strategic plans, are reorganising their institutions in order to obtain better scores, and are using the results to diagnose the strengths and weaknesses of their institutions.

If we adopted the criteria in one of the most popular rankings in the world, that of the Jiao Tong University of Shanghai ${ }^{i}$, better known as the Shanghai ranking, we would be identifying university quality with the number of former students and teachers of the institutions who have won the highest awards in the field of science, and also by the number of articles published in journals included in the indices of the Journal Citation Report, among other criteria.

In contrast, the view of the university that we propose here is based upon the principles of the human development approach. It is different from the prevailing reductionist view, but is, in our opinion, neither utopian nor naive. There are numerous official documents signed by university leaders that support the validity of such a proposal. For example, the Preamble of the Magna Carta of European Universities, prepared in 1988 and signed by hundreds of universities throughout the world, considers that 'the universities' task of spreading knowledge among the younger generations implies that, in today's world, they must also serve society as a whole [...] and that universities must give future generations education and training that will teach them, and through them others, to respect the great harmonies of their natural environment and of life itself”, (Magna Carta, 1998:1). ii

Several other international declarations have stressed the engagement required of universities towards human and sustainable development and the improvement of society as a whole. Those documents have been summarized in a valuable volume by the Global University Network for Innovation (GUNI, 2008, xvi-li) on Higher Education: New Challenges and Emerging Roles in Higher Education. We will highlight two of these documents: the World Declaration on Higher Education for The Twenty-First Century: Vision and Action, signed in 1998, ${ }^{\text {iii }}$ and the Talloires Declaration of $2005^{\text {iv }}$. 
The World Declaration on Higher Education for The Twenty-First Century: Vision and Action presents an agreement on what might be the main ends of a higher education institution. It is a milestone in the history of universities because it was formally adopted by representatives of the world academic community, by civil society representatives and by the governments of more than 180 countries at the World Conference on Higher Education, held at UNESCO in Paris in 1998. Dias (2002) summarizes these as the agreed four main goals: 1) the elaboration of new knowledge (the research function); 2) the education and training of high-level specialized people (the teaching function); 3 ) to provide services to society, especially through the contribution to a sustainable development and to the improvement of society; and 4) the ethical function that implies social critique, that allows an integral education and that trains people who are socially responsible, with initiative, capable of dialogue and motivated to build a better society.

The Talloires Declaration (2005), signed in the French city of Talloires by the heads of 17 universities from all around the world, is very relevant because it defends an engaged and socially committed vision of a university with an expanded civic engagement and with social responsibility programs through teaching, research and public service. It is a vision of a university which takes an active role, that practices and disseminates a way of doing based on ethical principles, which is engaged with all social actors, looking not only for economic opportunities, but also with the aim of empowering individuals and groups, increasing mutual understanding, and strengthening the relevance, reach and responsiveness of university education and research.

Along the same lines we find interesting work carried out by many Latin American universities which, in recent years, have been promoting university social responsibility policies that involve university learning, research, social outreach and governance. Among them, we can highlight the initiative of the Jesuit universities in Latin America (AUSJAL, 2009) and the University Builds Country project by Chilean universities (Universidad Construye País, 2006).

Besides international declarations, many academic studies of higher education have elaborated and defended this sort of perspective on what a university might and should 
be. Among them, we note the liberal visions of Nussbaum (1997) and Watson (2008); Kezar et al. (2005)'s model of a higher education institution for the public good; Ostrander (2004)'s civic/engagement model; Taylor (2007) on the participative university; Brennan and colleagues (2004) on the transformative university and Giroux and colleagues (2001) on critical education. The common point of all these authors is that the university should not be distant from the big problems the world faces nowadays environmental challenges, social injustices, armed conflicts, intolerance, abuses of and lack of respect for human rights - and that it should have an active role, engaged in local and global spaces, to foster and support an active, just and sustainable society.

We do not want to simplify the complex debate on what should be the role of a university. We acknowledge the great diversity among higher education institutions all around the world, under pressure from recent processes of massification, privatization, and public expenditure reduction. We want to stress the ethical perspective of a university both in its micro-dimension (the university seen as an organization together with all its immediate stakeholders) and in its relationship with its wider partners at the local, national and global levels. We argue in this paper that the human development (HD) framework can valuably contribute to define and characterize what a good university might be, and can stimulate new perspectives to define quality of universities.

\section{The human development approach contrasted with an economy- or market-centred conception of governance and society}

A reductionist conception of universities, to use the terminology coined by the Development Education Association and the Association of University Teachers in the UK (1999), can fit as part of a bigger conception of societal governance in which each type of organization has its own characteristic, radically distinctive, vocation:

0 the function of the business enterprise is to make profit, and only that, for it thereby contributes most to the greater good, according to Milton Friedman, David Henderson and similar apostles of capitalism (e.g., Friedman, 1962); 
$\bigcirc$ the function of the state is to provide the environment for the effective functioning of business; and

o the function of the university is to generate knowledge that is useful for business and the state and to train people to work for business enterprise and the state.

In this conception, the business enterprise should not meddle in promotion of the noneconomic good; the state should not attempt to run economic enterprises, and certainly not on non-profit principles; and the university should limit itself to teaching and research adjudged valuable by funders, and not focus on the roles of wider service to society and of social critique and rethinking that were mentioned earlier.

Ironically, those who argue against 'corporate social responsibility' rarely argue against the ability of corporations in most capitalist societies to intervene in political life. Corporations are treated as legal persons, able to allocate funds to political activity in the same way as are real individuals; but unlike real individuals, corporations allocate the funds that belong to their shareholders and stakeholders (Lindblom, 2002). They correspondingly manage vastly greater funds than almost any individual, and they have large infrastructures and staff to assign to political lobbying and campaigning whenever they see fit. '[Democratic] Societies do not permit their taxing authorities or their military forces or their ministries of agriculture to claim the civil rights of individual citizens. [Those organizations] are instead constrained to follow their assigned purpose and no others' (Lindblom, 2002: 240). But most capitalist democracies have allowed their democracy to become dominated by capitalist corporations. At the same time, defenders of such an arrangement are often critical of adoption of a broad social role by universities. In this paper we adopt a perspective in which universities, like corporations, are expected to account for their overall societal impacts. They thus require mechanisms to take these into account, in some of their processes of strategy, planning and evaluation.

This 'mind your own business' conception of societal governance rests on a model of a market-centred society, in which competitive markets are presented as able to organize most aspects of life in a desirable way - promoting liberty, prosperity and harmony more 
than will any alternative form of societal organization - provided they are suitably supported by a market-friendly state and a suitably business-friendly education sector.

Important assumptions behind this model of a market-centred society include the following. First, that human fulfilment centres on the acquisition and consumption of commodities. Second, that markets never significantly interfere with and compromise the operation of their environments, namely the state, the knowledge sector, the family, the natural environment, and the system of social norms; for example they do not bring pressures and concentrations of financial power that distort the operation of the electoral system, the legislature, the police and judiciary, the mass media, or the focus and conduct of the systems of education and research, nor do the dynamics of market society ever endanger the quantity and quality of family life, or the social bases of co-operation, reciprocity and solidarity. None of these assumptions stands up well to scrutiny (Lane, 1991; Lane, 2000; Lindblom, 2002).

Several alternative conceptions of societal governance stress the independent and equal importance and necessity of each of several different spheres of social activity and value (e.g.: Walzer, 1983; Miller and Walzer, 1995; Klamer, 2005; van Staveren, 2001), each with their own appropriate criteria and necessary autonomy, but each requiring an awareness of their potential impacts and actual impacts upon each other. If we do not accept a model of the world in which the only function for the business enterprise is to make profit, and we instead accept wider corporate social responsibilities, correspondingly we are unlikely to find acceptable the model of the university which accepts only narrow responsibilities.

The human development approach arises from such a tradition in humanist social philosophy and humanist economics (e.g., Haq, 1999; Nussbaum, 2000; Gasper, 2009). It stresses: a plurality of values, not only the values of economic utility as expressed and promoted within markets; secondly, a human-wide concern and solidarity, as in human rights philosophy: the field of reference is all humans, wheresoever in the world, and in particular all those affected by one's actions; and thirdly, it recognises the normality and 
centrality of interconnections: side-effects of markets mean that market calculation is insufficient even if we only use a value of economic utility. Human development theory, represented for example in the UNDP Human Development Reports, moves to analyse processes and connections not only within disciplinary and national boundaries. Economic policies towards low-income countries for example can have major wider impacts, on conflict and violence, the flow of arms and the creation or strengthening of international crime networks, disease, migration, international epidemics, and more.

Human development thinking contains thus a concern not only for increase of people's skills ("human resource development") or the so-called "human sectors"'(e.g. nutrition, health, education). It rests on a broad conception of human well-being, and sees development as the promotion and advance of well-being.. Further, besides an extended list of relevant human values in addition to those measured by markets, it rests on a picture of human identity and interconnectedness which leads us to see the rejection of broad corporate social responsibility and of broad university social responsibility as both imprudent and inhumane.

Haq (1999) summarised 'human development' as development for, by, and of people: a combination of humane priorities, thoroughgoing participation, and 'human resource development' ${ }^{\text {'v }}$. It is opposed to an 'inhuman development' that excludes some or most people, even from fulfilment of their most basic needs such as access to clean water and life-saving drugs. It rejects measuring performance solely by how much is bought and sold without reference to its composition (for example, whether it is guns or life-saving drugs) and its distribution, use and relationship to people's particular requirements. It insists on reference also to the important non-commodified goods and bads in life. Strong economic growth is easily combined with lack of adequate nourishment and of clean water for much of a country's population, notably for young children, to the extent of permanently damaging their mental and physical capacity and life quantity and quality. Indeed the growing incomes of some groups often raise prices and reduce access for poor groups and lead to their physical displacement. A human development approach includes 
strong emphases on participation and empowerment, in their own right and as essential in order to politically initiate and sustain this sort of equitable strategy.

Overall, a human development approach treats development as promotion of wellconsidered human values. Thus societal development is a normative concept distinct from economic growth and social change, whose value content must be assessed not presumed. The approach has broadened the range of objectives routinely considered in development debate and planning. UNDP's standard definition of dimensions of human development has covered: (1) empowerment, meaning the expansion of capabilities (ability to attain valued ends), expansion of valued functionings (attained valued ends), and participation (sharing in specifying priorities); (2) equity in distribution of basic capabilities, and the (3) security and (4) sustainability of people's valued attainments and opportunities. Penz et al. (2011)'s recent synthesis of work on human development ethics slightly extends this list by highlighting human rights and cultural freedom. Arguably these were already largely subsumed within the UNDP formulation, within the range of valued ends to be promoted, equitably distributed, sustained and secured, but are now further highlighted.

Amongst the aspects of human development thinking relevant for thinking about higher education institutions, let us mention three here: the role of preparation for participation in public reasoning; the role of preparation of emotionally enriched and matured persons, able to recognise, engage and take up responsibilities; and the role of provision of guidance for analyses about the responsibilities and potential contributions of universities themselves.

First, as presented by Haq, people are the key means as well as the valued end in development processes. Human development theory stresses popular empowerment as a means in social change, for example. But in addition, for the public goods which are central in human development the associated reasoning must be group reasoning and prioritisations must be through group processes. People must be well equipped to reason. This is the opposite of 'the banking approach [to education, which tacitly contains] the effort to turn men into automatons - the very negation of their ontological vocation to be 
more fully human. ... [In the banking approach] The educated man is the adapted man [taught what to think, and taught not to question] ... this concept is well suited to the purposes of the oppressors...' (Freire, 2007: 70).

So, second, in contrast to in narrow forms of 'human resource development', education is seen as the development of persons. 'Attempting to be more human, individualistically, leads to having more, egotistically: a form of dehumanization. ... some men's having must not be allowed to constitute an obstacle to others' having ...' (Freire, 2007: 74). Correspondingly, Martha Nussbaum's form of human development theory is found useful by many analysts of education. It involves close attention to the contents of people's lives, while looking at whole lives. This contributes to, she argues: seeing each person as distinct and deserving respect and concern; thinking hard about what is similar and what is different in their lives; and generating a picture of major aspects of life that each deserve respect and protection. Nussbaum $(1997,2000)$ discusses a series of basic capabilities-including for a full life span, health, practical reason, affiliation and political participation — needed for a life with dignity. Walker (2006) highlights several of these, including practical reason, respect and affiliation, plus emotional and interpersonal skills, imagination and curiosity, as particularly relevant criteria in designing and assessing higher education pedagogies.

Thirdly, the human development approach involves not only wide-ranging specifications of values and causes - and thus wide-ranging specification of ends and means - it uses values of human welfare, focused on how people do and can live, to guide choices of topics and boundaries of analysis in policy-oriented investigations (Gasper, 2008). That spirit can guide universities too in considering how to use their enormous potentials.

\section{Human Development and the quality of universities}

Can the Human Development approach really be used to offer ideas, to suggest a novel way of thinking, about the quality of universities? One of the main contributions of HD thinking has been to expand the range of goals usually considered in the field of 
development planning. Why not use a comparable line of thought for university policies in general, and university quality in particular? This section will first introduce elements of the debate on university quality, and then explore the contributions that HD thinking can make.

Even before the recent obsession with rankings, university quality and its management have been strongly on the agenda of university policy since the 1980s (Vroeijenstijn 1995). As Harvey (2005: 264) highlights, due to neoliberal thinking higher education was subject to accountability in terms of "efficiency and effectiveness" because governments want higher education to be more responsive in certain ways. Demands for various forms of reporting and accountability have increased. Self-regulation and operational autonomy for individual higher education institutions is accompanied by new instruments of external control, including accreditation, quality assurance assessments (audits), and program- or discipline- evaluations (Aas et al., 2009). Behind these new forms of control are several reasons. Harvey (2005) suggests the following factors: making higher education more relevant to social and economic needs; widening access to higher education; expanding numbers, usually involving decreasing unit costs; ensuring comparability of provision and procedures within and between institutions, including by international comparisons; ensuring students get value for money; and ensuring that institutions are able to cope with increasing globalization and the deregulation of the market.

In this context, the quality of higher education has been interrogated. In British higher education, by the early 1990s "quality" had evolved from having a marginal position in academic management to being the foremost concern alongside funding issues and expansions (Harvey, 2005). Much effort has gone into attempts to define simple, measurable quality indicators. At the same time the negative effects of heavy reliance on control by such indicators have been highlighted (Aas et al., 2009). There is, further, no consensus about what a good university is. Sanyal and Martin (2007:5) identify ten different definitions of quality: 1. providing excellence, 2. being exceptional, 3. providing value for money, 4. conforming to specifications, 5. getting things right the first time, 6 . 
meeting customers' needs, 7. having zero defects, 8. providing added value, 9. exhibiting fitness of purpose, and 10. exhibiting fitness for purpose.

We can agree with De Ketele (2008) that quality is a concept difficult to define due to its multidimensional and situation-relative nature. In the same sense, Sanyal and Martin (2007) suggest that because quality means different things to different stakeholders and it is difficult or impossible to reconcile all of these aspects, so the definition of quality is inevitably a political process.

Not only definition of quality is a controversial issue. Also, the measurement and management of quality is contentious. Brennan and Shah (2000) report on a study that drew upon 29 case studies conducted by higher education institutions in 14 countries of their experiences in quality assessment and their perceptions of its impact. The study revealed both similarities and important differences in quality assessment. In most of continental Europe, matters to do with curricula, staff appointments and promotions, awards and qualifications have been decided, at least formally, by the state. Elsewhere such matters have been decided within higher education institutions. As well as the particularities of national context, each higher education institution has its own contextual features that affect quality assessment. Central to the establishment of quality management and assessment systems, whether national or institutional, are questions of power and values: "Quality management represents a challenge to the intrinsic value system of the academic profession and is a mechanism through which extrinsic values of society and economy are given greater weight in academic institutional life" (Brennan and Shah, 2000: 331).

Hans van Ginkel and Marco Antonio Rodrigues Dias highlight that in the quality debate the key issue is who says what quality is. In this sense, tension exists between those points of view that try to homogenise some international standards, and others that advocate the relevance of local contexts. According to the authors, the former view, supported by the OECD and the WTO, does not consider local needs, contexts or diversity, de-contextualises the university and imposes criteria on countries in the South 
who, rather than being perceived as active partners, are considered as mere recipients (Van Ginkel and Dias, 2007). Contrary to this de-contextualised view is the stand advocated by the World Conference on Higher Education of 1998, which in its article \# 11.a defines quality as follows:

«"[...] quality in higher education is a multidimensional concept, which should embrace all its functions and activities: teaching and academic programmes, research and scholarship, staffing, students, buildings, facilities, equipment, services to the community and the academic environment. Internal self-evaluation and external review, conducted openly by independent specialists, if possible with international expertise, are vital for enhancing quality. Independent national bodies should be established and comparative standards of quality, recognized at international level, should be defined. Due attention should be paid to specific institutional, national and regional contexts in order to take into account diversity and to avoid uniformity. Stakeholders should be an integral part of the institutional evaluation process".

The 1998 World Conference definition includes interesting ideas related to the HD proposal. Firstly, the multi-dimension feature. This would mean not reducing quality to just a few indicators of success (as rankings do), but embracing different features of university activity: learning, research, facilities, services to the community, etc.

Secondly, diversity. Just as we mentioned diversity among all humankind when referring to $\mathrm{HD}$, here we refer to the relevance of local and regional institutional contexts in order to define quality criteria. Further, and here we refer to the third criterion, stakeholders participation would be one of the core elements in the definition of the said criteria.

Who are the stakeholders? If we think that universities should respond to the challenges of society, the stakeholders are all citizens, who, by using existing mechanisms or creating new ones, should take a greater part in defining university policies and activities. As Van Ginkel and Dias (2007:37-38) stress, to know what quality is, all university stakeholders should take part in defining what society expects from higher education 
institutions. HD thinking can contribute to our not forgetting the essential values in these processes: they require real mechanisms for participation, transparency and accountability in its broadest sense, in order to ensure that democratically made decisions are implemented.

Regrettably, the following World Conference on Higher Education, held in Paris in 2009, did not insist on this line of thought advanced in 1998. Reflecting the spread of a standardized managerialist style in many university systems worldwide, it stressed instead the establishment of quality assurance mechanisms and patterns of evaluation as well as promoting a 'quality culture' within institutions. But as to what 'quality' means, its use of the concept is more generalized and vague and without explicit emphasis on multidimensionality, diversity and multistakeholder perspectives.

\section{HD dimensions for assessment of the quality of universities}

We now present a proposal of dimensions which can be used to guide identification of criteria to assess university activities according to HD key values. It is a broad and incomplete proposal, intended to stimulate debates among different stakeholders and shareholders interested in rethinking university quality. As Watson (2008: 52-53) suggests, the possible groups of people interested could include prospective and current students, teaching, researching and administrative staff, investors and supporters, local communities, governments, other higher education institutions besides universities, etc.

Until now, scholarly work that uses Human Development thinking in respect to education has mainly concentrated on the meaning of education and the practice of pedagogy. Martha Nussbaum (1997), one of the most widely acknowledged authors, defends a Socratic view of education that places the examined life, the Aristotelian notion of reflective citizenship, and the Stoic view of education at the core of the educational task. It is a kind of education that sets us free from uncritically assumed habits and customs and empowers us to operate with sensitivity and awareness in the world. Furthermore, she 
proposes three fundamental capacities involved in the Stoic ideal of "cultivating humanity": critical self-examination, the ideal of being citizens of the world, and the development of narrative imagination (see also Gasper and George, 2010). Along the same lines, Melanie Walker (2006) proposes a list of theoretical-practical capacities that may be promoted by higher education: practical reasoning, knowledge and imagination, respect, dignity, acknowledgement, emotional integrity, bodily integrity, etc.

Our proposal involves attention also to other spheres of university work besides pedagogy and curriculum, including research and social engagement, as well as internal governance, the other policies of universities (for example on admissions and investment), and the physical environment of the institutions. We believe a powerful idea of quality connected to HD thinking must consider all the activities developed in a university and not only a limited vision of those activities related mainly with teaching and researching, as followed by current university rankings. The matrix that we present (Figure 1) provides a space to think about each of a series of core values for each of a set of major spheres or dimensions in university work.

Concerning the selection of the values of HD that appears in the matrix, we have chosen well-being, participation and empowerment, equity and diversity, and sustainability. This proposal is based on the work of Penz et al. (2011), who identify a set of core values that have come to frame debates over ethical development over the past 50 years. From their original proposal-human well-being and security; equity; empowerment; human rights; cultural freedom; environmental sustainability - the only value we have not included is human rights, which appears to overlap substantially with the others. Many of the aspects that would be grouped under this concept have been included for example under our values of equity and diversity.

To draw up our list of dimensions of university work, we have referred also to Hart et al.'s (2009) proposal for benchmarking public engagement, to various papers and documents in GUNI's series on the social engagement of universities (GUNI, 2008), and 
to our own previous work (Boni and Perez-Foguet, 2008; Boni and Berjano, 2009, Boni et al., 2011; Gasper, 1990).

[Somewhere around here: insert figure 1]

The matrix does not present specific indicators but instead identifies aspects that could be lead to concrete indicators in particular contexts. The selection and definition of indicators will depend on the instrument we will choose to measure or assess quality, for example whether the chosen instrument is a ranking or an evaluation or an accreditation. The matrix is, then, only a first step that must be completed by a second stage during which the most suitable instruments for a particular exercise will be chosen.

Examples of the possibilities of carrying out activities shown in the matrix can be found in the "Higher Education Good Practice Global Map"vi maintained and updated by the the Global University Network for Innovation (GUNI). The reader can also find examples in the edited books by Giroux and Myrsiades (2001), Kezar et al. (2005), Peters and Freeman-Moir (2006) and Unterhalter and Carpentier (2010). Another interesting example which connects HD thinking and university quality is by Singh (2011). She describes the work of the Higher Education Quality Committee of the Council on Higher Education in South Africa to embed into quality assurance the social justice goals of the country's post-1994 reform of higher education. As Singh highlights: "The quality agency decided to add a social justice lens to the traditional evaluation approach, premised on the need to re-think quality in a way that connected with the multiple social purposes of higher education specified in the 1997 Education White Paper 3 [which] includes equity and social transformation issues in addition to more familiar goals relating to labour market needs and economic growth" (Singh, 2011, p.489). Accordingly, "more diverse teaching and learning environments, a focus on student competences for living, working, making choices and acting in a democratizing world, [and] the development of new curricula and pedagogies which took transformation issues into account, and so on" were invoked as quality criteria (Singh, 2011, p.489). ${ }^{\text {vii }}$ 
In another work, Lange and Singh (2010), present an account of this experience describing how the South African Higher Education Quality Committee has developed an "institutional audit" and "programme accreditation" system to assess South African Universities considering social justice criteria. After five years of implementation, Lange and Singh (2010) remark institutional audits have had a considerable impact on institutional thinking and discussion on the relationship between equity and quality and on the development of initiatives focused on staff and student equity profiles. On the contrary, the programme accreditation system has not been totally implemented. In any case, this example of a different understanding of quality rooted in social justice thinking is perfectly compatible with human development values. Indeed, besides the ideas of social justice, which match the equity, security and human rights themes in human development, "the quality agency also drew on the idea of social transformation" (Singh, 2011, p.489), which draws too on the theme of empowerment. The matrix presented in this paper could be a source of inspiration to define possible activities to orient a university towards social justice. But, as the South African example highlights, decisive support from policy makers is essential, given that a managerial vision of quality centered on financial success and short-term results is nowadays dominant. Consistent with human development thinking, in which development is not equated automatically to what occurs in the most industrialized countries, this example of operationalizing the matrix's approach comes from a country in the global South.

\section{Conclusions}

We have emphasized a broad vision of the university and its potentials and responsibilities, based on a Human Development approach. Our proposal is strongly connected to higher education policies such as in the Magna Carta of European Universities, the Taillores Declaration of 2005 and the works promoted by the Global University Network for Innovation. We do not imagine that an approach to universities that is dominated by assessment of their functionality for the business sector, and by their own profitability seen as businesses, will suddenly be replaced. But evidently many universities and many stakeholders concerned with the future of universities seek to 
articulate and operationalize a broader vision. Just as businesses too are nowadays often subject to environmental audit, gender audit, and overall social responsibility audit, so too can and will be universities. To do this a corresponding evaluation framework is required, and we have attempted to motivate and sketch one such framework.

In contrast to the currently most widespread way of defining university quality we have presented an innovative perspective which stresses multidimensionality, diversity, participation and relevance to local contexts, among other criteria. A human-development oriented exercise to evaluate the quality of university work should involve wide participation of internal stakeholders and of stakeholders external to the university community. Likewise, it will have a strongly multidimensional understanding of quality, recognising multiple dimensions as regards the type of activities that should be included in evaluation (education, research, social engagement, university governance and policy, and the university living- and working- environment). Correspondingly, many different types of information should be gathered, with attention to university processes as well as to results and inputs. Working out such systems requires constant attention to the particularities of diverse activities of teaching, research and outreach, including their conventional disciplinary organization, and to pitfalls in conceptualization and measurement of 'quality' —or, as we argued, qualities — and corresponding attention to the purposes and real effects of such exercises. But quality assessment in universities will not disappear, and we wish to promote an alternative that will be helpful for some purposes, occasions and stakeholders, at the moments when a university is to be judged or planned with reference to broad human concerns. Universities which adopt, and perform well on, such evaluations may also become those which will attract the interest and support of students, funders and other sponsors who share such wider human concerns.

To implement a system to assess quality according to these criteria will be complex and indeed costly, just as the beginnings of the measurement of human development have been. We can imagine a new way of doing university evaluation which considers human development both in the content and in the process of conducting it; or we can think of a 
certification which includes new dimensions related to human development; or we can envisage a different form of ranking, which despite the inherently reductionist nature of rankings, could hopefully have a long and fruitful trajectory just as the Human Development Index has had. As the South African example suggested, application of the same principles to higher education is both feasible and important.

\section{Acknowledgments}

We would like to thank the Spanish Ministry of Education who granted Boni's fellowship at the Institute of Social Studies in Erasmus University Rotterdam in 2009. We also acknowledge the advice of two anonymous referees and of Melanie Walker, plus, discussions and exchanges with Hans van Ginkel, with colleagues and especially with members of the Education study group of the Human Development and Capability Association.

\section{References}

Aas, G.H., B. Askling, K. Dittrich, W. Froestad, P. Haug, K.H. Lycke et al. (2009) 'Assessing educational quality: Knowledge production and the role of experts'. Helsinki: ENQA.

Altbach, P.G. 2008. The complex roles of universities in the period of globalization in GUNI ed. pp 5-14

AUJSAL (2009), Politicas y Sistema de Autoevaluación y gestión de la responsabilidad social universitaria, Alejandría Editorial, Córdoba.

Boni, A. and Pérez-Foguet, A., (2008). Introducing development education in technical universities: successful experiences in Spain. European Journal of Engineering Education, 33 (3), pp. 343-354.

Boni, A. and Berjano, E., 2009. Ethical learning in higher education. The experience of the Technical University of Valencia. European Journal of Engineering Education, 34 (2), pp. 205-213.

Boni, A., MacDonald, P. Peris, J. (2011), Cultivating engineers' humanity: Fostering cosmopolitanism in a Technical University, International Journal of Educational Development, In Press, doi:

10.1016/j.ijedudev.2011.07.001

Brennan, J. and T. Shah (2000) 'Quality assessment and institutional change: Experiences from 14 countries', Higher Education 40(3): 331-349.

Council of the European Union (2007) Council Resolution on modernising universities for Europe's competitiveness in a global knowledge economy Retrieved. from http://register.consilium.europa.eu/pdf/en/07/st16/st16096-re01.en07.pdf.

DEA/AUT (Development Education Association/Association of University Teachers) (1999), Globalisation and Higher Education. Guidance on Ethical Issues Arising from International Academic Activities, DEA/AUT, London

De Ketele, J-M (2008), "The social relevance of higher education" in GUNI (2008) Report on Higher Education in the World 3. London: Palgrave, pp. 55-59. 
Dias, Marco Antonio, 2002, "Lecciones de la Conferencia Mundial sobre Educación Superior: "Perspectivas de la Educación Superior en el Siglo XXI" - M.A. Rodrigues Dias (coordinador) Conferencia de Rectores de las Universidades Españolas (CRUE) y Fundación Universitaria de Cooperación Internacional- 2002. Avalaible at http://www.mardias.net/ [retrieved 21th December].

Freire, P., 1970. Banking versus Problem-Solving Conceptions of Education. Ch. 2 of Pedagogy of the Oppressed. Reprinted in R. Curren (ed), 2007, Philosophy of Education: An anthology. Pp.68-75

Friedman, M., 1962. Capitalism and Freedom. Chicago: University of Chicago Press.

Gasper, D, 1990: Subnational Planning and Planning Education - implications of their changing environment and practice. Pp.261-303 in Subnational Planning in Southern and Eastern Africa, eds. A.H.J. Helmsing \& K. Wekwete, Aldershot: Avebury Publishers.

Gasper, D., 1993: Policy Analysis and Evaluation - an agenda for education and research. Working Paper 140, ISS, The Hague.

Gasper, D., 2008. From 'Hume's Law' To Policy Analysis For Human Development - Sen after Dewey, Myrdal, Streeten, Stretton and Haq. Review of Political Economy, 20(2), 233-256.

Gasper, D. 2009: 'Human Development'. Chapter 31, pp. 230-237 in Handbook of Economics and Ethics, eds. J. Peil \& I. van Staveren (Cheltenham: Edward Elgar).

Gasper, D., and George, S. (2010) 'Cultivating Humanity? Education and Capabilities for a global "Great Transition", Working Paper 503, The Hague: Institute of Social Studies.

Giroux, H. A. and Myrsiades, K. (2001) Beyond the Corporate University: culture and pedagogy in the new millennium Lanham: Rowman \& Littlefield.

GUNI. 2008. Report on Higher Education in the World 3. London: Palgrave.

Hart, A., S. Northmore and C. Gerhardt (2009) 'Briefing Paper: Auditing, Benchmarking and Evaluating Public Engagement'. Bristol: National Co-ordinating Centre for Public Engagement.

Harvey, L. (2005), 'A history and critique of quality evaluation in the UK', Quality Assurance in

Education, 13(4), 263-276.

Haq, M. ul (1999) Reflections on Human Development, $2^{\text {nd }}$ edition, Oxford University Press, Delhi.

Hazelkorn, Ellen (2007), "The Impact of League Tables and Ranking Systems on Higher Education Decision Making”, Higher Education Management and Policy Vol.19 Issue 2,

Lane, Robert, 1991. The Market Experience. Cambridge, Cambridge University Press.

Lane, Robert, 2000. The Loss of Happiness in Market Democracies. New Haven: Yale U.P.

Lange, L., and Singh, M. (2010) 'Equity issues in quality assurance in South African higher education', in Equity and quality assurance : A marriage of two minds, ed. M. Martin, 37-73. Paris: IIEP/UNESCO.

Lindblom, Charles, 2002. The Market System, Yale University Press, New Haven.

Kezar, A., A.C. Chambers J.C. Burkhardt (2005) Higher Education for the Public Good: Emerging Voices from a National Movement, Jossey-Bass, San Francisco.

Klamer, A. (2005) In hemelsnaam! Over de economie van overvloed en onbehagen. Uitgeverij ten Have, Kampen.

Miller, D., and Walzer, M. (eds., 1995), Pluralism, Justice and Equality, Oxford: Oxford University Press.

Morin, Edgar (2000), Les septs savoirs necessaires a l'education du futur. Paris:Seuil.

Naidoo, R. (2003) 'Repositioning Higher Education as a Global Commodity: Opportunities and Challenges for Future Sociology of Education Work', British Journal of Sociology of Education, 24(2), 249259.

Nussbaum, M. (1997) Cultivating Humanity. A classical defense of reform in liberal education. Cambridge, MA: Harvard University Press.

Nussbaum, M., 2000. Women and Human Development. Cambridge, Cambridge University Press.

OECD (2007) Higher Education and Regions: Globally Competitive, Locally Engaged. Paris, Organization for Economic Co-operation and Development.

Olssen, M. and Peters, M. A. (2005) 'Neoliberalism, Higher Education and the Knowledge Economy: from the free market to knowledge capitalism', Journal of Education Policy, 20(3), 313-45;

Ostrander, Susan A. 2004. Democracy, Civic Participation, and the University: A Comparative Study of Civic Engagement on Five Campuses. Nonprofit and Voluntary Sector Quarterly, 33 (1): 74-93.

Penz, P., J. Drydyk, P. Bose (2011) Displacement by Development: Ethics, Rights and Responsibilities. Cambridge: Cambridge University Press.

Peters, M. and Freeman-Moir, J. (2006) Edutopias: New utopian thinking in education Rotterdam: Sense Publishers. 
Sachs, J. (dir), 2005, Millennium Project of United Nations, Investing in Development, Millenium Project, New York, 2005. Avalaible at http://www.unmillenniumproject.org/reports/index.htm [retrieved 21th January 2010].

Sanyal, B.C. and M. Martin (2007) 'Quality assurance and the role of accreditation: an overview', in Higher Education in the World 2007 : Accreditation for quality assurance : what is at stake? (pp. 3-23). Basingstoke [England] and New York: Palgrave Macmillan.

Singh, M. (2011), "The place of social justice in higher education and social change discourses" in Compare: A Journal of Comparative and International Education, 41:4, 481-494.

Staveren, I. van, 2001, The Values of Economics, London: Routledge.

Sumner, A. "What are the ethics for development Studies", IDS Bulletin, 2007, 38, 2. Pp. 59-68.

Taylor, P. (2007) "Higher Education and Participatory Development", GUNI Newsletter, 26 June. Available at http://www.guni-rmies.net/newsletter/viewNewsletter.php?int boletin=137 [retrieved $6^{\text {th }}$ July 2009].

Taylor, P. (2008), "Introduction" in GUNI, 2008, Report on Higher Education in the World 3. London: Palgrave, pp. Xxiv-xxvi.

Universidad Construye País (2006), Una manera de ser Universidad, Santiago de Chile, Edición Proyecto Universidad Construye País,.

Unterhalter, E. and V. Carpentier (2010) Global Inequalities and Higher Education, Whose Interests Are We Serving? Houndmills: Palgrave MacMillan.

Van Ginkel, Hans J. and M.A. Rodrigues Dias, (2007), "Retos institucionales y políticos de la acreditación en el ámbito internacional” en GUNI, La educación superior en el mundo 2007: La financiación de las Universidades, Mundiprensa, Madrid, Pp. 48-49.

Van Ginkel, H., and Rodrigues Dias, M.A. (2009) "Institutional and Political Challenges of Accreditation at the International Level" in Higher Education at the Time of Transformation. New Dynamics for Social Responsibility. GUNI series on the Social Commitment of Universities, Hampshire Palgrave McMillan:, pp. 162-166.

Vroeijenstijn, A.I. (1995) Improvement and Accountability: Navigating between Scylla and Charybdis. Guide for External Quality Assessment in Higher Education.: Taylor and Francis: Bristol, PA.

Walker, M., 2006. Higher Education Pedagogies, Maidenhead, UK: Open University Press and The Society for Research into Higher Education.

Walshe, J. (2007) “OECD: Worldwide 'obsession' with league tables” University World News Reports, 5, 11 November, http://www.universityworldnews.com/article.php?story=20071108144018483 [retrieved 13th July 2009)

Walzer, M. (1983) Spheres of Justice, Oxford: Blackwell.

World Bank (2002) Constructing Knowledge Societies. New Challenges for Tertiary Education, World Bank: Washington. 
i This ranking can be viewed at http://www.arwu.org/index.jsp (retrieved 15 September 2011).

ii Available at http://www.magna-charta.org_[retrieved 18th August 2011].

${ }^{\text {iii }}$ Available at http://www.unesco.org/education/educprog/wche/declaration eng.htm [retrieved 18th August 2011].

iv Available at http://www.tufts.edu/talloiresnetwork/?pid=17 [retrieved 18th August 2011].

${ }^{v}$ The following description builds on Gasper 2009.

vi The good practices con be viewed on the Universities and Social Commitment Observatory at http://www.guni-rmies.net/info/default.php?id=110 [retrieved 18th August 2011].

vii In another work, Lange and Singh (2010), present an account of how the South African Higher Education Quality Committee has developed an "institutional audit" and "programme accreditation" system to assess South African Universities considering social justice criteria. For instance, to assess 